\section{IMAGE UNAVAILABLE FOR COPYRIGHT REASONS}

Anyone out there? The sequence of bottles in the exhibit at MIT matches that of the 1974 code.

\section{Bottled radar pays tribute to Sagan}

[BOSTON] Visitors entering Building 68, the new biology facility at Massachusetts Institute of Technology (MIT), will have been struck this month by an imposing row of wooden structures spanning the length of the corridor along the building's facade.

The structures consist of 18 racks housing 1,679 glass bottles, some filled with water, others empty. The sequence of the bottles replicates the sequence of radar pulses and pauses of a coded message that was transmitted into space in 1974 by astronomers Frank Drake and Carl Sagan from the Arecibo Observatory in Puerto Rico.

The message conceived by Drake and Sagan was sent in the hope that extraterrestrial listeners might decipher it and learn about the building blocks of life, the structure of DNA, the number of nucleotides in the human genome and other facts about life on the third planet from the Sun.

'A Message in Many Bottles' is the work of Joe Davis, an artist and research affiliate with MIT's Laboratory of Molecular Structure. Davis has dedicated the installation to the memory of Carl Sagan, who died last year. The MIT Council of the Arts, which deemed the work "insufficiently artistic" to receive funding on its debut in 1988 , provided $\$ 250$ this time around for moving expenses.

The exhibit, which is on show until early April, pays homage to Sagan's legacy, part of which consists of the radio signal that is propagating towards the globular star cluster M13 in the Hercules constellation, 25,000 light-years from Earth.

Philip Sharp, chairman of MIT's biology department, describes the exhibit as a "fitting tribute" to Sagan's work. "It brings the abstraction of a radar message into an accessible, physical form," says Sharp. He says he sees "numerous benefits" in having an artist who approaches issues from an unorthodox perspective working alongside more formally trained scientists.

SteveNadis

\title{
NIH is likely to challenge genetic 'probe' patents
}

[WASHINGTON] The National Institutes of Health (NIH) are likely to contest a decision by US patent officials to allow the patenting of expressed sequence tags (ESTs) - short sequences of DNA that uniquely identify full-length expressed genes.

Last Friday (21 March), the NIH sent a letter to the Patents and Trademarks Office (PTO), arguing that ESTs do not meet the office's own definition of practical utility. The letter also urges the PTO to make as narrow as possible the scope of EST patents that NIH believes are legitimate because the ESTs in question correspond to known genes.

NIH's director, Harold Varmus, had said earlier that he was "concerned" about a recent decision by the PTO to consider applications for such patents on a case-by-case basis (see Nature 385, 755; 1997).

PTO officials argue that ESTs alone can be legitimately patented because of their utility as molecular probes. The decision comes despite a continuing debate in the scientific community about the usefulness of ESTs as well as concern that rights to one could encompass rights to the full-length gene, and discourage further research on that gene.

Reflecting broad concern among scientists about the implications of the decision, Varmus said that "this is an issue that we are likely to publicly contest". He added: "Exactly how that kind of patent would be issued, what rights would be given to the patent holder, are not yet known." And he warned that the patenting of such research tools could produce "disincentives to develop products and possibly strong disincentives to do the research that's required". Varmus was speaking at a seminar on biomedical research at Brookings Institution in Washington DC.

Clarisa Long, a molecular biologist and attorney who is an intellectual property expert at the American Enterprise Institute, defended the PTO's decision as reversing the previously existing "legal fiction" that ESTs lacked utility unless the function of their corresponding gene was disclosed. She also challenged the claim that narrow patents on such sequences would impede further research.

But this view is contested by Rebecca Eisenberg, a professor of law at the University of Michigan, and an adviser to NIH on intellectual property issues. "A proliferation of patent rights [under which a researcher] would need licences creates a problem for downstream product development," she says, adding that patents on multiple ESTs might have that effect for products related to therapeutic proteins, or products encoded by the sequences.

\section{Law urged to check genetic discrimination}

[WASHINGTON] Guidelines for legislation to prevent discrimination by employers against individuals on the basis of their genetic characteristics was made public last week by a consortium of US government advisers on the social and ethical implications of genetic research and breast cancer activists.

The proposals coincide with growing public concern in the United States about the implications of genetic testing for jobs and health insurance. They also follow the introduction of several bills in Congress that seek to outlaw genetic discrimination.

The recommendations have been drawn up by the National Institutes of Health/Department of Energy Working Group on the Ethical, Legal and Social Implications of Human Genome Research (the ELSI working group) in collaboration with the National Action Plan on Breast Cancer, an organization with representatives from both the government and the private sector. They follow similar guidelines on genetic discrimination in health insurance published by the same group in October 1995.

In a paper published in Science, the group recommends that employers should be barred from making promotion, pay and other benefits conditional on genetic information, unless they can prove that the information is job-related and "consistent with business necessity". In such cases, they would need to get an employee's written and informed consent for collection or release of the information.

The group also proposes that employers should be banned from requiring genetic information or testing before offering a job, and banned from gaining access to genetic information in employees' medical records. Employees alleging discrimination would be able to file private lawsuits against employers.

At present, there are few legal constraints preventing US employers from requiring employees to take genetic tests. Restrictions on employers' use of 'genetic information' - a broad term that includes physical characteristics and family history - are even more scarce. 